\title{
Trade-off between Employment and Job Quality: Ethnic Penalty in Italian Regional Labour Markets
}

\author{
By Maurizio Avola*
}

In just a few decades, South Europe has become one of the most important destination areas for migratory flows coming from high emigration countries. The immigrant labour market integration in this area, however, differs significantly compared to the experience of older Centre-North European receiving countries. Although many cross-national studies have examined the role of some macroinstitutional variables that may affect the process of immigrant integration, the main reason for these differences seems to be due to the characteristics of the labour market. Italy may prove an important case study to explore this issue in greater depth, given that within the same institutional context, the labour market performances, structure and informal regulation differ significantly at a territorial level, with many Northern regions more comparable to Centre-North European countries, while those of South highlighting Mediterranean characteristics. Indeed, the aim of this study is to verify if, and to what extent, the differentiation of the labour market characteristics influence the modalities of immigrant socio-economic insertion also at a regional level within the same country. In particular, it focuses on the relationship with native labour forces and the so-called ethnic penalty, namely the differences between immigrants and natives emerging in the labour market performances when as many individual characteristics as possible are taken into account. The results of the multivariate analysis carried out confirm the existence of a trade-off among the Italian regions similarly to what is found in the comparison between South and Centre-North Europe: immigrants have better employment entry chance where the size of the secondary labour market is bigger, but at their expense in terms of job quality. However, gender specificities emerge too, making some clarifications necessary.

*Associate Professor of Economic and Labour Sociology, Department of Political and Social Sciences, University of Catania, Italy. 


\section{Introduction}

International migratory dynamics have seen many changes in the last thirty years, first and foremost the gradual differentiation in the areas of origin and destination of the flows (Castles and Miller 1993; Massey et al. 1998). Also for this reason, besides the traditional focus on the ethnic aspects of immigrants, the analysis of the institutional characteristics of host societies, including the structure and regulation of the labour market, has become increasingly important to comprehend the processes of reception and integration (Reitz 2002; Büchel and Frick 2005; Heath and Cheung 2007; Kogan 2007; Sá 2008; Pichler 2011; Reyneri and Fullin 2011a; Ballarino and Panichella 2013).

To study differentiation of the immigrant labour market integration in host societies, the Italian case seems particularly interesting from an international perspective. Indeed, it offers specific national features that are useful for crossnational researches: like Greece, Portugal and Spain, Italy is a latecomer and has profoundly different socio-economic and institutional characteristics (labour market structure and regulation, welfare regime, immigration and integration policies, etc.) compared to older Centre-North European and overseas receiving countries.

Italy is also interesting from an internal point of view, since inside the country and within its regulatory system, the productive structure, economic performances in terms of GDP, income and per-capita consumption and the mismatch between labour demand and supply, just like every other important socio-economic indicator, are markedly differentiated along the North/South axis. Not surprisingly, the imbalances characterizing the country have historically represented the background within which the size and profile of immigrant labour insertion was territorially differentiated, in terms of employment opportunities, distribution by sectors, occupations and working conditions (Ambrosini 2001; Pugliese 2002; Strozza, Forcellati and Ferrara 2008; Avola 2009; 2012; Reyneri 2011).

This study hopes to contribute to the debate by proposing an analysis that starting off from these regional differences explores the consequences from the viewpoint of the relationship of the occupational performances between immigrants and natives, referring in particular to the size and structure of the ethnic penalty (Berthoud 2000; Heath and Cheung 2007).

The paper is organized as follows. After presenting the theoretical framework and a synthesis of the results of previous studies on this topic, the hypotheses of the research will be illustrated (para. 2). The data used and the methodology are then described (para. 3), while in the fourth paragraph the results are presented. Finally, the last section (para. 5) is dedicated to some conclusive reflections, especially on the implications of the results of the Italian case towards defining different models of the immigrant labour market integration that may also prove useful in an international perspective. 


\section{Theoretical Framework and Research Hypothesis}

Comparison with the autochthonous population is a key element in order to evaluate immigrant labour market integration in a host society. From an empirical point of view, almost all analyses focus on the levels of participation, employment and unemployment in the labour market, on the one hand, and on the socio-professional attainment (mainly sociologists) and earnings (mainly economists), on the other. However, to assess the specific differences due to the condition of immigrants, any comparison with natives needs to consider ethnic status as having an independent effect on the labour market performance. Indeed, the heterogeneous socio-biographic composition of the two populations may affect levels and modality of access in the economic system. For this reason, apart from the gross advantage/disadvantage, some scholars suggest calculating ethnic penalty in terms of the differences between immigrants and natives emerging when as many individual characteristics as possible (sex, age, level of education, family status, etc.) are taken into account (Berthoud 2000; Heath and Cheung 2007; Reyneri and Fullin 2011b) ${ }^{1}$.

Alongside the relationship with natives, the increasing institutional heterogeneity of receiving countries has prompted many researchers to also evaluate the impact of some macro-level variables that may affect the process of employment integration of immigrants. These include the rigidity/flexibility of the formal regulation of the labour market, the existence of specific immigration and integration policies, the regime of prevailing welfare and the structure of national labour markets, mainly by making reference to the size of the secondary labour market (Büchel and Frick 2005; Kogan 2007; Sá 2008; Pichler 2011; Reyneri and Fullin 2011a; Ballarino and Panichella 2013).

According to these empirical strategies, considering both gross ratio and ethnic penalty as described above, some cross-national studies have observed deep differences of the immigrant labour market integration between old and new immigration countries, particularly in Western Europe. In the older receiving countries of the Centre-North, comparative analyses show that immigrants face considerable gross disadvantage or ethnic penalty in their access to the labour market (they are much less likely to be employed and risk being unemployed even more so). In Southern European countries, instead, from this perspective the differences are less relevant or non-existent and in some cases the relationship is reversed (Kogan 2007; Reyneri and Fullin 2011a; 2011b; Ballarino and Panichella 2013). However, at a job quality level (largely measured considering the EGP, ISCO and ISEI classifications of professions) there is a significant reversal of the scenario: although at all latitudes immigrants are concentrated in less skilled jobs compared to natives, the degree of segregation and the relative levels of ethnic penalty are greater precisely in Southern European countries (Pichler 2011; Reyneri and Fullin 2011b; Cingano et al. 2013). To sum up, as highlighted by Reyneri and Fullin

${ }^{1}$ In this way we may get approximately the net advantage (or disadvantage) of being immigrant (or native). 
(2008; 2011b), compared to what we can see in the Centre-North European countries, the immigrant labour market integration in Southern Europe seems characterized by a trade-off between employment entry chances (or risk of unemployment) and job quality.

Beginning from these findings, we applied a similar empirical strategy in previous studies to analyse the Italian case from a territorial perspective, comparing the Centre-North and South of the country (Avola 2012; 2014). Although the two macro-areas are characterized by the same institutional order, the performance, structure and informal regulation of labour market differ considerably. Compared with the Centre-North, the South of Italy has a significantly lower employment rate and higher unemployment rate, but also a wider secondary labour market in terms of: a more undeveloped process of tertiarization and a widespread incidence of unskilled, low paid, poorly protected, precarious and irregular jobs. From this starting point, according to Kogan (2007) and Reyneri and Fullin (2011a), we may expect that in a context with a larger secondary labour market, immigrants have higher employment entry chances (and risk unemployment to a lesser extent), thereby facing a lower degree of penalty than natives. The reasons for better employment chances for immigrants and reduced penalty compared to the native-born may be ascribed to mechanisms regulating the matching between labour demand and supply at lower levels on the occupational hierarchy. In the first place, in this segment of the labour market the competition between foreign and native labour forces is limited, since the latter are less willing to offer themselves for poorly paid, unstable and low skilled jobs. In the second place, employers would not run a high risk by taking on unknown workers (immigrants), since hired workers can easily be disposed of. Nonetheless, the price paid for the low penalty in terms of employment entry chances would be high, as shown by the trade-off mechanism between access to the labour market and job quality highlighted in cross-national researches cited above.

The results of these previous comparative studies between the CentreNorth and South of Italy have shown that the Italian situation, in its "national" dimension, is the result of a composition of different models of the immigrant labour market integration between the two macro-areas of the country. Undoubtedly, the Centre-North is a little less "Mediterranean" and for certain aspects rather more akin to the old European receiving countries. In this macroarea, for example, the prevailing profile of the immigrant as an industrial manual worker in a certain sense echoes the guest-worker characterizing the migratory inflows in the Centre-North European industrialized countries after the Second World War (Castles 1986). Moreover, concerning the relationship with the autochthonous labour force, in the Centre-North of Italy the immigrants are affected by the traditional multiple disadvantage/ethnic penalty: their probabilities of being employed are lower than for natives, while unemployment risk is higher and there is a widespread penalty for all the aspects of the job quality considered. The South of Italy, instead, accentuates the typical features of the South European model of the immigrant labour market integration. First of all, the demand for immigrant labour is mainly 
concentrated in agriculture, construction, hotels and restaurants, small trade and above all household assistance and care. Secondly, considering ethnic penalty, a peculiar combination between advantage in terms of access to the labour market and very high penalty (more so than in the Centre-North) in attaining more highly skilled, better paid, stable and socially recognized jobs, has been found for immigrants living in this area of the country.

At this point, we would take a further step in testing our hypothesis from a regional perspective, focusing on the issue of ethnic penalty. The reason for this choice is twofold. First, the differentiation in labour market performance and structure is very broad inside the same macro-areas ${ }^{1}$. Extending then the analysis to all Italian regions may increase the generalizability of our findings. To sum up, recalling the arguments of Kogan (2007) and Reyneri and Fullin (2011a) cited above and already used in the comparison between Centre-North and South of Italy (Avola 2012; 2014), we may expect that the penalty of the immigrants compared to natives concerning access into the labour market is smaller in the regions where the dimensions of the secondary labour market are bigger (hypothesis 1). On the other hand, considering previous findings in the comparison among Western European countries and between the Centre-North and South of Italy, the ethnic penalty regarding job quality is characterized by a trade-off with respect to the employment status penalty: where immigrants are less penalized in terms of access into the labour market, they pay for it in terms of wider segregation in the lower level of the occupational hierarchy and worse working conditions (hypothesis 2).

\section{Data and Methods}

The study has been conducted using a data set of the Italian Labour Force Survey from 2005 to 2011. The large sample size and the use of a seven year time series ensure sufficient representations of immigrants also at a regional level, namely what interests us most here. Note, however, that the data of the two smallest Italian regions (Valle d'Aosta and Molise) have been merged with those of the neighbouring and most similar ones (respectively Piedmont and Abruzzo) and that the analysis focuses only on the working age population (1564 years).

In order to answer our main questions, we have adopted a multivariate analysis, with models of separate logistic regression by region of residence and gender. To evaluate ethnic penalty in terms of access to the labour market we use a dichotomous dependent variable, distinguishing between employed and not employed (unemployed and inactive population). We refer instead to three dichotomous dependent variables to estimate ethnic penalty in terms of job

\footnotetext{
${ }^{1}$ According to Eurostat data at the level of territorial divide NUT2, for every year considered Italy is among the first EU countries with highest level of dispersion of regional employment and unemployment rates. Other significant differences are also found on the employment distribution by sector and profession.
} 
quality. The first includes all the employed and concerns the socio-professional attainment, distinguishing between semi and unskilled manual workers, on one hand, and white collars, petty bourgeoisie and skilled manual workers, on the other ${ }^{1}$. The second and third dependent variables regard only employees, considering employment security and wages, respectively. For employment security, we decided to merge the stability of the contract (permanent vs nonpermanent) and the firm size (up to or more than 15 employees $^{2}$ ) and distinguish less secure employees (non-permanent employees and permanent employees in firms of up to 15) from those more secure (permanent employees in firms with more than 15). Indeed, the last dummy considers employees with a net monthly wage in the first quartile of the annual distribution from the others.

The key independent variable of the binary regression models is represented by the population groups recorded beginning from the country of birth, also using the information on citizenship to limit the risk of including the children of Italians born abroad in the category of immigrants. For these reasons, therefore, the population has been classified into three main groups:

- born in Italy (natives) as reference category;

- born in European Union countries at 15 or in other OECD countries and "returning Italians",

- immigrants from high emigration countries (hereafter immigrants).

The other independent variables inserted in the models (dummy coded) are referred to the observed individual characteristics that may affect labour market performances:

- age groups with five categories (15-24 - ref., 25-34, 35-44, 45-54, 55-64);

- level of education with four classes (no school and primary - ref., lower secondary, upper secondary, tertiary);

- family status with five classes (single - ref., married/cohabiting without children, married/cohabiting with children, youths living with parents, single-parent).

\footnotetext{
${ }^{1}$ This variable has been recorded beginning from the EGP classification (Erikson, Goldthorpe and Portocarero 1979). The choice to isolate the semi and unskilled manual workers derive from the high concentration of immigrants in this category, more than $50 \%$ in the South and among women in the Centre-North.

${ }^{2}$ It's a formally and symbolically important threshold for the Italian case. Employees working on firms up to 15 have less opportunities of access to income maintenance policies, weaker trade-union rights and protection against dismissal.

${ }^{3}$ To simplify the reading, the data related to those born in the UE at 15 , other OECD and "returning Italians" will not be reported, nor commented (even if the group is included in the regression models presented further on). This is a particular grouping of foreigners, whose profile of labour market integration and performances are radically different to those of immigrants coming from high emigration countries and very similar to those of natives.
} 
Finally, we also include in the models the year of observation (2005 ref.). In all the regression models used here, reference is made to the average marginal effects (AME) and not $\beta$ coefficients. By this latter, instead, the average marginal effects do not in fact present problems of comparison between different models or similar models that refer to different samples, to groups within the same sample (as in the models presented here) and to different survey periods (Mood 2010). To simplify reading the data the estimation of the average marginal effects are reported in percentages, considering a confidence interval of $95 \%$.

\section{Results}

As shown in Table 1, the Italian labour market is characterized by widespread differences among regions both in terms of employment opportunities and incidence of secondary labour market ${ }^{1}$. The gap in terms of employment rate between Trentino A.A. and Calabria is almost $20 \%$ for men, and between Emilia R. and Campania is more than $30 \%$ for women. There are also significant differences inside the same macro-areas, as demonstrated by the cases of Sardinia and especially Abruzzo and Molise in the South. Moreover, the imbalances in terms of access to employment are associated with those of the diffusion of the secondary labour market, the size of which grows precisely where the labour demand is weaker, namely in the South.

The most interesting aspect is that the data reported in Table 1 seem to confirm our first research hypothesis for both sexes. The ethnic penalty in terms of access to the labour market varies significantly among the regions, decreasing when the dimensions of the secondary labour market become bigger. In greater detail, in all the Northern regions the ethnic penalty level of immigrants is significant (except for women in Liguria), in those of South the penalty is always reversed (except for women in Abruzzo and Molise), while in the Centre we found an intermediate situation.

\footnotetext{
${ }^{1}$ As a proxy for the secondary labour market has been calculated the impact on total employment of those unskilled manual workers with less secure condition for the employees (non-permanent and permanent in firm of up to 15) and in a low level position for the selfemployed (contributing family workers, members of a cooperative, para-employees and selfemployed without employees).
} 
Table 1. Employment Rate (E.R.), Percentage of employed in Secondary Labour Market (SecLM) and Ethnic Penalty in Terms of Access to the Labour Market (E.P. $)^{a}$ by Gender and Region

\begin{tabular}{|l|c|c|c|c|c|c|}
\cline { 2 - 7 } \multicolumn{1}{c|}{} & \multicolumn{3}{c|}{ Male } & \multicolumn{3}{c|}{ Female } \\
\cline { 2 - 7 } \multicolumn{1}{c|}{$\begin{array}{l}\text { Piedmont and V.A. } \\
\text { (N1) }\end{array}$} & SecLM & E.P. & E.R. & SecLM & E.P. \\
\hline Lombardy (N2) & 7,7 & 7,5 & $-5,1$ & 56,1 & 9,5 & $-11,9$ \\
\hline Trentino A.A. (N3) & 77,1 & 7,9 & $-2,9$ & 56,1 & 9,1 & $-13,4$ \\
\hline Veneto (N4) & 76,0 & 7,7 & $-3,9$ & 54,0 & 8,8 & $-14,0$ \\
\hline Friuli V.G. (N5) & 73,2 & 6,8 & $-3,0$ & 55,2 & 6,8 & $-12,0$ \\
\hline Liguria (N6) & 72,0 & 7,6 & $-1,1$ & 54,0 & 8,8 & 0,1 \\
\hline Emilia R. (N7) & 76,5 & 8,1 & $-1,2$ & 61,1 & 8,8 & $-14,3$ \\
\hline Tuscany (C1) & 73,9 & 8,9 & 1,2 & 55,0 & 10,3 & $-2,7$ \\
\hline Umbria (C2) & 72,7 & 8,9 & $-2,3$ & 53,8 & 12,0 & $-7,4$ \\
\hline Marche (C3) & 73,1 & 9,2 & $-1,6$ & 54,7 & 10,3 & $-12,7$ \\
\hline Lazio (C4) & 70,5 & 8,5 & 1,4 & 48,5 & 11,8 & 2,3 \\
\hline $\begin{array}{l}\text { Abruzzo and Molise } \\
\text { (S1) }\end{array}$ & 68,6 & 9,0 & 5,5 & 43,7 & 8,0 & $-10,2$ \\
\hline Campania (S2) & 57,5 & 10,8 & 12,7 & 27,0 & 12,9 & 19,6 \\
\hline Puglia (S3) & 61,9 & 13,8 & 7,4 & 29,2 & 14,1 & 11,4 \\
\hline Basilicata (S4) & 62,8 & 11,6 & 10,7 & 34,8 & 12,9 & 10,0 \\
\hline Calabria (S5) & 57,0 & 15,7 & 10,2 & 30,9 & 19,2 & 16,9 \\
\hline Sicily (S6) & 59,1 & 15,3 & 13,2 & 28,9 & 11,0 & 13,2 \\
\hline Sardinia (S7) & 63,7 & 12,5 & 9,9 & 39,9 & 11,8 & 7,7 \\
\hline North & 75,1 & 7,7 & $-3,0$ & 56,4 & 8,9 & $-12,8$ \\
\hline Centre & 72,1 & 8,8 & 1,0 & 51,7 & 11,1 & $-1,6$ \\
\hline South & 60,2 & 12,9 & 10,5 & 30,8 & 12,7 & 11,9 \\
\hline Italy & 69,3 & 9,5 & 4,1 & 46,3 & 10,2 & $-0,7$ \\
\hline Sour I, & & & & & \\
\hline
\end{tabular}

Source: Istat, LFS 2005-2011.

a) Likelihood of being employed. Results of binary logistic regression models controlled for age, education, family status and LFS year. AME estimate (percentage values) for immigrants (reference natives).

The next step in our analysis is the relationship between the previous penalty levels in terms of access to the labour market and that referring to the socio-professional attainment of immigrants with respect to the natives. The scatter diagrams in Figure 1 are very significant. First of all, immigrants are considerably penalized everywhere, women more so than men. However, there is a trade-off only for men. For the latter it is evident that when the employment penalty decreases (or turns to advantage) the segregation of immigrants at lower levels of the occupational hierarchy grows significantly. Except for Abruzzo and Molise, in all the Southern regions we find a combination between advantage in terms of access to the labour market and very high ethnic penalty in shying away from semi and unskilled manual work. Instead, for women the trade-off is not entirely clear. 
Figure 2 and 3 regard only employees, considering the relationship between the ethnic penalty in terms of employment entry chances, on one hand, and respectively employment security and wage penalty, on the other. The scatter diagrams reinforce our previous findings on the existence of a trade-off for men: the relationship is undeniable for wages, while it is less evident for employment security. Taking into consideration the women, however, there seems to be no trade-off once again, both for employment security and wages.

Figure 1. Relationship between Employment Penalty and Socio-professional Penalty at Regional Level. Results of Binary Logistic Regressions controlled for Age, Education, Family Status and LFS Year. AME Estimate (percentage values) for Immigrants (Reference Natives)

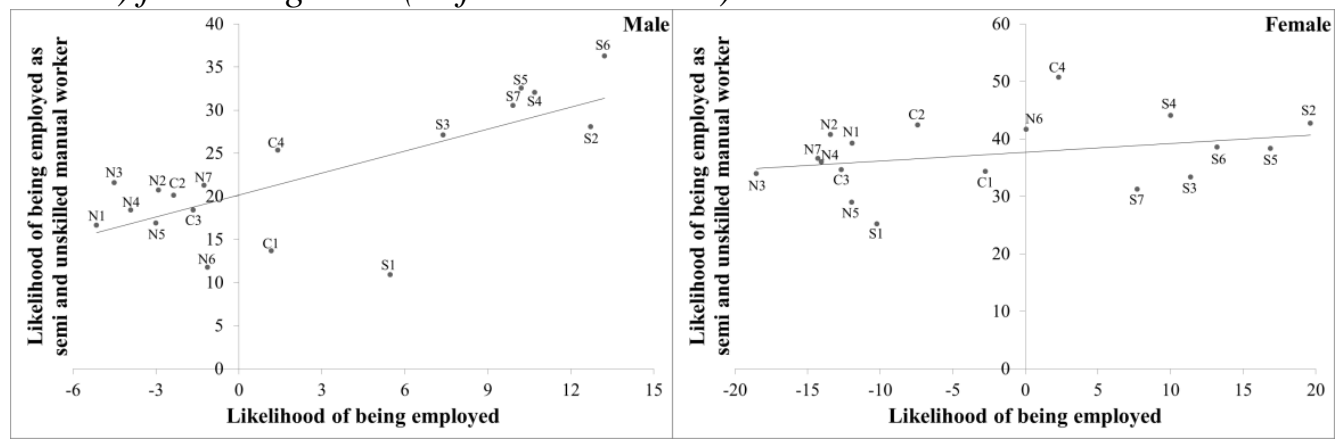

Figure 2. Relationship between Employment Penalty and Employment Security Penalty of Employees at Regional Level. Results of Binary Logistic Regressions controlled for Age, Education, Family Status and LFS Year. AME Estimate (Percentage Values) for Immigrants (Reference Natives)

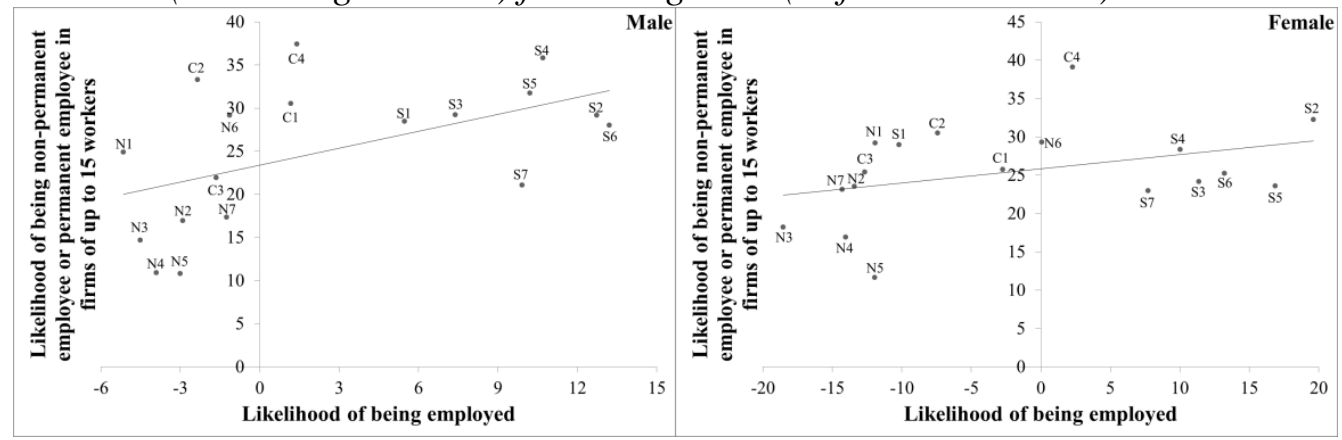


Figure 3. Relationship between Employment Penalty and Wage Penalty of Employees at Regional Level. Results of Binary Logistic Regressions controlled for Age, Education, Family Status and LFS Year. AME Estimate (Percentage Values) for Immigrants (Reference Natives)

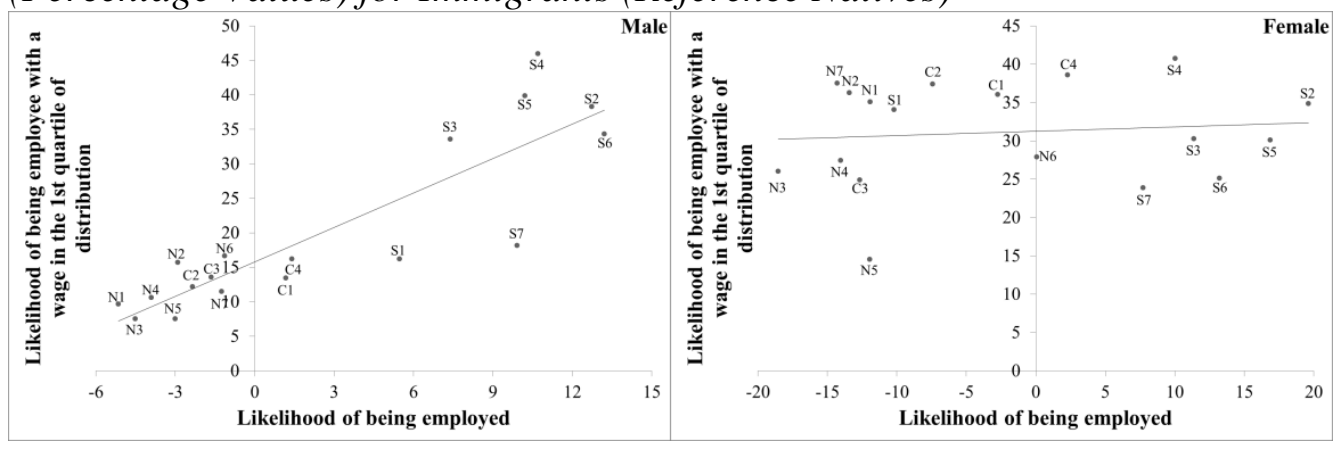

To summarise the results of this part of the analysis, we may conclude that our second hypothesis is partially confirmed. As observed comparing CentreNorth and South of Italy (Avola 2012; 2014), in a cross-regional perspective the penalty of male immigrants compared to natives regarding segregation on the lower rungs of the socio-professional hierarchy, wages and to a lesser extent employment security, increases simultaneously with the reduction of penalty in terms of access to the labour market. These findings suggest that the competitiveness of immigrants in the most problematic regions in terms of employment opportunities and presence of a significant secondary labour market (with the relative substantial flexibility connoting it) is based on their widespread willingness to accept bad jobs. These are generally jobs with poor added value, doing unskilled manual tasks and with low social recognition, in organizational contexts beyond the area of industrial citizenship and often at extreme disadvantage in terms of pay and contractual guarantees. Instead, there is not such a clear-cut confirmation for women. Unlike men, female immigrants perform a common function in compensating for the institutional weakness of the Italian welfare system: their access to the labour market is closely linked to the mismatch between the growing need for assistance and care and the inadequate public offer. Therefore, they are equally segregated in unskilled, insecure and low paid jobs without any significant relationship to the regional differentiation of employment entry chances penalty (the latter essentially linked to the considerably different level of labour market participation of female natives, especially those with lower education which in the Southern regions is about half that in the Northern ones).

\section{Conclusions}

The regional perspective adopted in this study in the ethnic penalty analysis offers new insights on the inconsistency of the Italian model of immigrant labour market integration in its "national" dimension. As previous studies have shown, our results corroborate the hypothesis of a significant 
trade-off across the country between immigrant employment opportunities and the quality of their jobs. This finding confirms the results of a recent comparative analysis between old and new immigration countries in Western Europe (Reyneri and Fullin 2008; 2011b), and which provides important insights for a better definition of the Southern European model of the immigrant labour market integration (King 2000; King and Ribas-Mateos 2002; Baganha 2009; Peixoto et al. 2012). The cross-regional differences emerging in the Italian case do not diminish the explanatory power of the model, as some researchers assert (Baldwin-Edwards 2012), but rather explain the specificity beyond any simple geographic labelling of the phenomenon, or exclusively connected to some institutional characteristics.

One lesson we can draw from the Italian case of ethnic penalty, above all in the Southern regions, is that the Mediterranean model of immigration is driven by the characteristics of the labour markets in the South European countries: the persistent and widespread incidence of a secondary segment in a context of an increasingly educated youth supply enhances the mismatch between expectations and job opportunities for natives. This dynamic process, induced by the inadequate and worsening demand with respect to the training and education of the native population (Cortese and Spanò 2012), creates a growing opportunity of insertion for immigrants in spite of persistent problematic macro-economic scenarios and labour markets. With their lower acceptance threshold compared to natives, immigrants bear the brunt of the imbalances of a society characterized by increasing levels of education and by life and consumption styles grounded in models of more advanced Western economies, but at the same time by a labour demand incapable of evolving along a path of innovation and reskilling, remaining over time unskilled, unstable, poorly paid, little protected and socially penalizing.

Secondly, the cross-regional analysis suggests just how important the active function of immigrants is in stimulating a demand for labour that would otherwise remain unexpressed, even in particularly problematic socioeconomic contexts like the South European countries. With their willingness to carry out heavy and socially penalizing work of domestic collaboration and caretaking, immigrants have altered the lifestyles of the local populations. They encourage, for instance, the externalisation of family caring, in a context of particularly poor public welfare, mounting family fragility, important demographic changes and greater emancipatory demands by women. Favouring the creation of a "new" demand tailored to their thresholds of acceptance of employment conditions, immigrants have thus become removed from the competition of natives in specific segments of the labour market. Where these processes are relatively more widespread, as in the Southern Italian regions, they end up by downscaling (or overturning) penalty in terms of job access, but they also contribute to increasing that related to the quality of the work.

This study urges some reflection on the evolution of the Italian labour market in the last decades. The growing imbalance between expectations and 
job opportunities for natives ends up by augmenting the probabilities of immigrant integration in the labour market, but at the same time accentuates the segregation in bad jobs, risking establishing an ethnic-based economic and social stratification that a territory of new immigration has never known before. To a certain extent the same has happened in the other South European countries, making policies aimed at avoiding job exploitation and, more generally, promoting social inclusion of immigrants necessary. At the moment, however, coastal and border controls and the countering of unauthorised entries seem to be the only measures implemented by governments and "supported" by the European Union.

\section{References}

Ambrosini M. 2001. La fatica di integrarsi. Immigrati e lavoro in Italia, Il Mulino, Bologna.

Avola M. 2014. "The Ethnic Penalty in Italian Labour Market: A Comparison between the Centre-North and South". Journal of Ethnic and Migration Studies, (published on line in early view).

Avola M. 2012. "Immigrazione e mercato del lavoro nel Mezzogiorno: eppur si muove". Mondi Migranti, 3, 53-80.

Avola M. 2009. "Paese che vai lavoro che trovi. La pluralizzazione dei modelli territoriali di inserimento occupazionale degli immigrati". In M.T. Consoli (a cura di), Il fenomeno migratorio nell'Europa del Sud. La Sicilia tra stanzialità e transizione, Franco Angeli, Milano, 35-56.

Baganha M.I. 2009. "Il modello migratorio dell'Europa Meridionale". In M.T. Consoli (a cura di), Il fenomeno migratorio nell'Europa del Sud. La Sicilia tra stanzialità e transizione, Franco Angeli, Milano, 23-33.

Baldwin-Edwards M. 2012. "The Southern European Model of Immigration. A sceptical view". In M. Okolski (ed.), European Immigrations. Trends, Structures and Policy Implications, Amsterdam University Press, Amsterdam, 149-157.

Ballarino G., and Panichella N. 2013. "The Occupational Integration of Male Migrants in Western European Countries: Assimilation or Persistent Disadvantage?". International Migration, (published on line in early view).

Berthoud R. 2000. "Ethnic Employment Penalties of Immigrants in Britain". Journal of Ethnic and Migration Studies, 26, 3, 383-407.

Büchel F., and Frick J.R. 2005. "Immigrants' economic performance across Europe does immigrations policy matter?". Population Research and Policy Review, 24, $1,175-212$.

Castles S. 1986. "The Guest-Worker in Western Europe - An Obituary". International Migration Review, 20, 4, 761-778.

Castles S. and Miller M.J. 1993. The age of Migration. International Population Movements in the Modern World, Macmillan, London.

Cingano F., Giorgi F. and Rosolia A. 2013. "Lavoro, retribuzioni e vulnerabilità". In C. Saraceno, N. Sartor and G. Sciortino (a cura di), Stranieri e disuguali. Le disuguaglianze nei diritti e nelle condizioni di vita degli immigrati, Il Mulino, Bologna, 87-109.

Cortese A. and Spanò A. 2012. "Introduzione. Pluralità e mutamento dell'immigrazione nel Mezzogiorno". Mondi Migranti, 3, 31-52. 
Erikson R., Goldthorpe J.H. and Portocarero L. 1979. "Intergenerational class mobility in three Western European societies: England, France and Sweden". The British Journal of Sociology, 30, 4, 415-441.

Heath A.F. and Cheung S.Y. (eds.) 2007. Unequal Chances. Ethnic minorities in western labour markets, Oxford University Press, Oxford.

King R. 2000. "Southern Europe in the Changing Global Map of Migration". In R. King, G. Lazaridis and C. Tsardanidis (eds.), Eldorado or Fortress? Migration in Southern Europe, Macmillian, London, 3-26.

King R. and Ribas-Mateos N. 2002. "Towards a diversity of migratory types and contexts in Southern Europe". Studi Emigrazione/Migration Studies, 145, 5-25.

Kogan I. 2007. Working through Barriers. Host country institution and immigrant labour market performance in Europe, Springer, Dordrecht.

Massey D.S., Arango J., Hugo G., Kouaouci A., Pellegrino A. and Taylor J.A. 1998. Worlds in Motion. Understanding International Migration at the End of the Millennium, Clarendon Press, Oxford.

Mood C. 2010. "Logistic Regression: Why We Cannot Do What We Think We Can Do, and What We Can Do About It". European Sociological Review, 26, 1, 6782.

Peixoto J., Arango J., Bonifazi C., Finotelli C., Sabino C., Strozza S. and Triandafyllidou A. 2012. "Immigrants, markets and policies in Southern Europe. The making of an immigration model?" In M. Okolski (ed.), European Immigrations. Trends, Structures and Policy Implications, Amsterdam University Press, Amsterdam, 107-147.

Pichler F. 2011. "Success in European Labour Markets: A Cross-National Comparison of Attainment between Immigrants and Majority Populations". International Migration Review, 45, 4, 938-978.

Pugliese E. 2002. L'Italia tra migrazioni internazionali e migrazioni interne, Il Mulino, Bologna.

Reitz J.G. 2002. "Host Societies and the reception of Immigrants: Research Themes, Emerging Theories and Methodological Issues". International Migration Review, 36, 4, 1005-1019.

Reyneri E. 2011. Sociologia del mercato del lavoro II. Le forme dell'occupazione, Il Mulino, Bologna.

Reyneri E. and Fullin G. 2011a. "Ethnic penalties in transition to and from unemployment: A West European perspective". International Journal of Comparative Sociology, 52, 4, 247-263.

Reyneri E. and Fullin G. 2011b. "Labour Market Penalties of New Immigrants in New and Old Receiving West European Countries". International Migration, 49, 1, 3157.

Reyneri E. and Fullin G. 2008. "New immigrations and labour markets in western Europe: a trade off between unemployment and job quality?". Transfer, 14, 4, 573-588.

Sá F. 2008. "Does Employment Protection Help Immigrants? Evidence from European Labour Markets". IZA Discussion Papers, n. 3414.

Strozza S., Forcellati L. and Ferrara R. 2008. "Il lavoro degli stranieri residenti nelle diverse Italie: differenze di genere e per cittadinanza". Rivista Italiana di Economia Demografia e Statistica, 62, 1, 99-128. 
